\title{
Neutrophil Extracellular Traps in Coronavirus Disease-19- Associated Ischemic Stroke: A Novel Avenue in Neuroscience
}

\author{
Tjokorda Istri Pramitasuri ${ }^{1}$, Anak Agung Ayu Putri Laksmidewi ${ }^{2 *}$, \\ Ida Bagus Kusuma Putra ${ }^{2}$ and Felix Adrian Dalimartha ${ }^{3}$ \\ ${ }^{1}$ Doctoral Program of Medical Sciences, Faculty of Medicine Udayana University, Denpasar 80232, \\ ${ }^{2}$ Department of Neurology, Faculty of Medicine Udayana University-Sanglah Academic General Hospital, Denpasar 80232, \\ ${ }^{3}$ Department of Neurology, Abdi Waluyo Hospital, Jakarta 10310, Indonesia
}

Ischemic stroke is one of the catastrophic neurological events that are being increasingly recognized among Coronavirus Disease (COVID)-19 patients. The recent studies have revealed about a possible connection among COVID-19, ischemic stroke, and excessive Neutrophil Extracellular Traps (NETs) formation. This paper establishes an overview of coronaviruses and NETs, NETs in pathogenesis of COVID-19 induced-ischemic stroke, and future directions using related recent literatures. NETs are normally functioned for a defense against pathogens, but in immoderate amount, they can trigger series of destructive events. Vasculopathy and neuroinflammation are the pathological mechanisms of NETs suggested to link COVID-19 and ischemic stroke. Based on newly discovered possible mechanisms, the potential clinical implications that could be applied consists of inhibition of NET formation, disrupting cholesterol synthesis, and interfering inflammatory pathway. A considerable number of scientific works are needed in order to complete the current understanding of the emerging relationship among COVID-19, NETs, and ischemic stroke. Although the exact mechanism is still unknown, these novel findings are a worthwhile contribution in defining future studies, suitable future frameworks, and therapeutic strategies.

Key words: Stroke, Coronavirus, Neutrophil, Extracellular traps

\section{INTRODUCTION}

For these past few months, our world has been facing the catastrophic spread of the newest member of the coronavirus family called Severe Acute Respiratory Syndrome-Coronavirus 2 (SARS$\mathrm{CoV}-2$ ), which has been identified as the etiology of Coronavirus Disease-19 (COVID-19). Countries are currently facing its devastating domino effects, which have affected all sectors of lives. Healthcare professionals are taking extensive efforts to make a quick and precise diagnosis in order to make the optimal decisions

Submitted September 28, 2020, Revised November 26, 2020,

Accepted December 25, 2020

* To whom correspondence should be addressed. TEL: 62-361-223-867, FAX: 62-361-246-082 e-mail:putri_laksmidewi@unud.ac.id related to the therapy. Studies have revealed that SARS-CoV-2 may induce ischemic strokes in human brains. Recently, five cases of large vessel stroke-related COVID-19 in young patients were reported in New York. Indeed, these cases have raised concerns among neurologists [1].

As global efforts to fight the current coronavirus pandemic along with its deteriorating complication, the ischemic stroke, continue, new studies have placed the potential role of overactive neutrophils under the spotlight $[2,3]$. Recently, despite there being some currently established mechanisms of ischemic stroke, researchers have become curious to explore a newly discovered role of Neutrophil Extracellular Traps (NETs), which are networks of DNA, histones, and proteolytic enzymes produced by activated neutrophils in stroke pathogenesis [3]. Indeed, an association between the SARS-CoV-2 infection and the formation of NETs were investigated in some recent studies. Moreover, a study that documented
Copyright ( ) Experimental Neurobiology 2021. www.enjournal.org
This is an Open Access article distributed under the terms of the Creative Commons Attribution Non-Commercial License (http://creativecommons.org/licenses/by-nc/4.0) which permits unrestricted non-commercial use, distribution, and reproduction in any medium, provided the original work is properly cited. 
high levels of NETs in patients with COVID-19 revealed that excessive NETs contribute to inducing disseminated inflammation, cytokine release, and microvascular thrombosis [4]. On the other hand, the biomarkers of NETs formation; citrullinated histone H3 (H3Cit) and cell-free DNA (cfDNA), were elevated during ischemic stroke. These findings propose a novel link among COVID-19, the formation of NETs, and ischemic stroke.

Although the exact mechanism is still unknown, understanding the role of NETs in the pathogenesis of stroke-related COVID-19 is a worthwhile contribution to defining suitable future therapeutic strategies. This paper presents an overview of coronaviruses and NETs, suggests the pathogeneses of NET-induced COVIDrelated ischemic stroke, and the future directions.

\section{COVID-19-INDUCED ISCHEMIC STROKE}

Acute Ischemic Stroke (AIS) is a catastrophic neurological emergency which induced by various risk factors, either modifiable or non-modifiable. Infection is one of established modifiable risk factors that do elevate the odds of getting stroke by 1.4-fold [5]. A recent case series study in New York comparing two groups; stroke patients who have confirmed with COVID-19 infection and another group of stroke patients without infection, revealed that COVID-19 was an independent risk factor for stroke in hospitalized patients [6]. Recent findings have reported several events of stroke in severe COVID-19 infection, whereas ischemic stroke is more frequent than intracerebral hemorrhage (Table 1).

A systematic review evaluating studies correlating AIS and COVID-19 revealed a high mortality rate [12]. Large vessel occlusion has determined as the underlying pathology in majority of COVID-19-related AIS cases. On the other hand, the traditional trends of AIS subtypes demonstrated higher incidence of small vessel stroke [13]. The common imaging patterns of ischemic stroke found in COVID-19 patients are stenosis and multiple territory pattern [12]. Another difference found between conventional AIS and COVID-related AIS is on the outcome. COVID-19 patients with AIS shows more significant incidences of hemorrhagic transformation, higher National Institutes of Health Stroke Scale (NIHSS) score, and increased mortality rate [9]. Factors related with higher possibility of in-hospital death in COVID-19-related AIS are ICU admission, high levels of C-reactive protein, lactate dehydrogenase, and D-dimer [14]. A systematic review revealed that there is a prolonged time of AIS onset in COVID-19 patients, ranged from 8 until 10 days [12]. Furthermore, a study observed a prolonged time to symptom recognition and presentation of COVID-19-related AIS, limiting the optimization of acute reperfusion therapy [15]. Owing to the tendency of having a large vessel occlusion and higher mortality on COVID-19 patients, the prothrombotic and cytokine storm are the possible underlying mechanisms of direct relationship between COVID-19 and ischemic stroke, although further researches need to be elucidated. Early detection of specific markers involved in the pathogenesis of COVID-related AIS can be a groundbreaking invention to choose the appropriate therapeutic interventions.

\section{NEUTROPHIL EXTRACELLULAR TRAPS}

Neutrophil Extracellular Traps (NETs) was initially characterized in 2004 [16]. They are extracellular structures, web-like in shape, containing nuclear DNA, histones, and proteolytic enzymes expelled from cell death of activated neutrophils [3] which has essential function to bind, degrade, and eliminate pathogens $[2,16]$. It was extensively discussed in vast amount of studies related to bacterial infection before being explored in the pathogenesis of viral infection [17]. The mechanism of cell death performed by NET (Neutrophil Extracellular Trap-osis; NETosis) is a distinguishable mechanism from either apoptosis or necrosis [2]. Main function of NET is related to host defense against pathogens including viruses and bacterium, which are killed by NET-associated proteins. On the other hand, excessive NET formation triggers the destructive inflammatory cascades which lead into organ damage and promotes other catastrophic events such as metastatic process of

Table 1. Clinical studies of strokes in COVID-19

\begin{tabular}{|c|c|c|c|c|c|c|}
\hline \multirow[t]{2}{*}{ Year } & \multirow[t]{2}{*}{ Country } & \multirow[t]{2}{*}{ Patient population } & \multirow{2}{*}{$\begin{array}{c}\text { Total number } \\
\text { of COVID-19 } \\
\text { patients }\end{array}$} & \multicolumn{2}{|c|}{$\begin{array}{c}\text { Incidence of each stroke } \\
\text { subtype (\%) }\end{array}$} & \multirow[t]{2}{*}{ Citation } \\
\hline & & & & Ischemic & Hemorrhagic & \\
\hline 2020 & United States & Laboratory confirmed COVID-19 & 86 & 83.7 & 16.3 & Katz et al. [6] \\
\hline 2020 & China & Laboratory confirmed COVID-19 & 214 & 2.3 & 0.4 & Mao et al. [7] \\
\hline 2020 & Italy & Laboratory confirmed COVID-19 & 388 & 2.5 & 0 & Lodigiani et al. [8] \\
\hline 2020 & United States & Laboratory confirmed COVID-19 & 3,556 & 0.9 & 0 & Yaghi et al. [9] \\
\hline 2020 & France & Severe COVID-19 & 150 & 2.0 & 0 & Helms et al. [10] \\
\hline 2020 & Netherlands & Severe COVID-19 & 184 & 2.7 & 0 & Klok et al. [11] \\
\hline
\end{tabular}


cancer and endothelial dysfunction [18].

The formation of NET is a series of regulated processes involving some key enzymes; Neutrophil Elastase (NE), Myeloperoxidase (MPO), Peptidyl Arginine Deiminase type 4 (PAD4), and gasder$\min \mathrm{D}$. NE is a neutrophil serine protease resides in azurophilic granules which breaks down intracellular proteins and induce disintegration of nucleus [3]. Together with MPO, NE started its role upon activation and Reactive Oxygen Species (ROS) production. Translocation of NE into nucleus followed by histones cleavage and promotes decondensation of chromatin. In the late stage of the process, MPO binds to chromatin and promotes further decondensation. Final result of these cooperative enhancement of chromatin decondensation leads into cell rupture and NET release [19]. Along with other enzymes, Gasdermin D (GSDMD), a poreforming protein, takes an important role in disrupting cell membrane. It also triggers the ejections of DNA and associates with molecules required in NETosis [20].

Another key molecule is Peptidyl Arginine Deiminase 4 (PAD4), a $74 \mathrm{kDa}$ protein [3]. It promotes the decondensation and release of the chromosomal DNA. PAD4-deficient mice were unable to exhibit all those processes linked with formation of NETs [21, 22]. PAD4 citrullinates arginine residues of histone $\mathrm{H} 3$-resulted in formation of H3Cit- prior to NETosis or formation of NETs [23]. Together with cell-free DNA (cfDNA), H3Cit considered as a surrogate biomarker to show the presence of NETs formation even after cerebral ischemia [24]. H3Cit serves as a specific marker of NETs formation, while cfDNA has less specificity as a NET-related biomarker [25].

\section{COVID-19 AND NETS}

There are increasing evidences to suggest that in the case of COVID-19, NETs play a significant role as the potential drivers of exacerbation and worsening of outcome [26]. Neutrophilia is a hallmark of acute infection in COVID-19 and could also be a source of excess NETs [3]. A recent autopsy findings from a COVID-19 patient revealed that there was a high density of neutrophil infiltration found in pulmonary blood vessels [27].

There are some reasons believed to be the cause of those findings. The elevation of Granulocyte-Colony Stimulating Factor (G-CSF) levels found among COVID-19 patients, even higher in severe cases [28]. The up-regulation of G-CSF, thus, obtains neutrophil out of bone marrow into circulation. It also reduces levels of C-X-C motif ligand (CXCL)-12, an important compound from the bone marrow which functions to clear out aged PMN [29]. CXCL2 and CXCL8, the NF- $\kappa \mathrm{B}$ driven neutrophil attractant chemokines, increased in sera of COVID-19 patients [30].

Patients with severe COVID-19 infections have higher neutrophil counts and less amount of lymphocytes [31]. Along with that, high level of neutrophil-to-lymphocyte ratio (NLR) has known as an independent risk factors of severe COVID-19 [32, 33]. However, several meta-analysis have shown that elevated NLR indicated bad prognosis of AIS and spontaneous intracerebral hemorrhage $[34,35]$. Neutrophils have known to interact with platelets to enhance immune system for fighting against pathogens. The interaction of them will stimulate neutrophil to release more neutrophil mediators and produce NETs [36]. The problem will be started if there is a massive formation of NETs which induces proinflammatory cascades along with tissue damages. Surprisingly, this idea was

Table 2. Studies of NETs in COVID-19

\begin{tabular}{|c|c|c|c|c|}
\hline Author, year & Patients & Biomarkers & $\begin{array}{l}\text { Method used in } \\
\text { measurement of NETs }\end{array}$ & Results \\
\hline $\begin{array}{l}\text { Nicolai et al., } \\
2020[37]\end{array}$ & $\begin{array}{l}38 \text { COVID- } 19 \text { patients and } 24 \\
\text { non-COVID-19 controls }\end{array}$ & H3Cit, MPO & Immunofluorescence & $\begin{array}{l}\text { NETs detected in inflammatory microvas- } \\
\text { cular thrombi located in the lung, kidney, } \\
\text { and heart }\end{array}$ \\
\hline $\begin{array}{l}\text { Zuo et al., } 2020 \\
\text { [38] }\end{array}$ & $\begin{array}{l}22 \text { COVID- } 19 \text { patients who } \\
\text { developed thrombosis and } 22 \\
\text { COVID-19 patients without } \\
\text { clinical thrombosis }\end{array}$ & $\begin{array}{l}\text { cfDNA, MPO, } \\
\text { H3Cit }\end{array}$ & $\begin{array}{l}\text { Quant-iT Pico Green } \\
\text { dsDNA Assay Kit (for } \\
\text { dsDNA) and ELISA (for } \\
\text { MPO and H3Cit) }\end{array}$ & $\begin{array}{l}\text { All NETs markers associated with higher } \\
\text { risk of morbid thrombotic events }\end{array}$ \\
\hline $\begin{array}{l}\text { Middleton et al., } \\
2020[39]\end{array}$ & $\begin{array}{l}33 \text { COVID- } 19 \text { patients and } 17 \\
\text { healthy controls }\end{array}$ & MPO & ELISA & $\begin{array}{l}\text { Plasma MPO-DNA complexes significantly } \\
\text { elevated in COVID-19 patients and cor- } \\
\text { related with illness severity }\end{array}$ \\
\hline $\begin{array}{l}\text { Veras et al., } 2020 \\
{[40]}\end{array}$ & $\begin{array}{l}32 \text { COVID- } 19 \text { patients and } 21 \\
\text { healthy controls }\end{array}$ & MPO, H3Cit & Immunostaining & $\begin{array}{l}\text { Neutrophils from COVID-19 patients } \\
\text { released statistically higher levels of NETs } \\
\text { compared with healthy controls }\end{array}$ \\
\hline
\end{tabular}

AIS, Acute Ischemic Stroke; dsDNA, double-stranded DNA; ELISA, Enzyme-Linked Immunosorbent Assay; NE, Neutrophil Elastase; MPO, myeloperoxidase; NET, Neutrophil Extracellular Traps; H3Cit, citrullinated histone H3; cfDNA, cell-free DNA. 
supported by some recent evidences about the presence of NETs biomarkers in severe cases of COVID-19 (Table 2).

\section{ISCHEMIC STROKE AND NETS}

As high levels of neutrophils identified in cerebral thromboemboli, it brings out a suspicion about the contribution of NETs in thrombogenesis and its role in decreasing efficacy of intravenous thrombolysis among Acute Ischemic Stroke (AIS) patients [41]. The neutrophils being the first blood-borne immune cells to arrive at ischemic brain tissues, binding various adhesion molecules in order to attaching themselves to endothelium within 15 minutes of ischemic stroke [42, 43], produces proinflammatory cytokines, chemokines, and cytotoxic molecules that accelerate the progression of brain damage [44]. It has known that the recruitment of neutrophils into the brain was orchestrated by IL-1. After being translocated, neutrophils will activate themselves, changes their phenotypes and releases decondensed DNA threads known as NETs [45]. These events have seen in a study conducted by Perezde-Puig et al. which observed the presence of H3Cit, the specific marker of NETs formation, in the ischemic brain after 24 hours
[24]. Kang et al. found that Ly6G-positive neutrophils, F4/80positive macrophages/microglia, Ibal-positive microglia, NeuNpositive neurons, and glial fibrillary acidic protein (GFAP)-positive astrocytes express H3Cit after stroke. Studies that investigated NETs in ischemic stroke, either in human or animal models, identified significant difference of the amount of NETs related-markers positive cells found in ischemic brain and healthy controls (Table 3 and 4).

\section{COVID-19, NETS, AND ISCHEMIC STROKE: A POSTULATED LINK}

Revealing the link among COVID-19, NETs, and ischemic stroke-related COVID is similarly to constructing a picture from puzzle pieces. Kang et al. shown that $\mathrm{H} 3 \mathrm{Cit}$ positive cells existed inside blood vessels and cerebral parenchyma [50]. Thus, the main points of the link between COVID-19 and ischemic stroke are closely related to two events: atherosclerosis along with thrombus formation in blood vessels and neurotoxicity in cerebral parenchyma [52].

Table 3. Human studies of NETs in stroke

\begin{tabular}{|c|c|c|c|c|}
\hline Author, year & Patients & Biomarkers & $\begin{array}{l}\text { Method used in } \\
\text { measurement of NETs }\end{array}$ & Results \\
\hline $\begin{array}{l}\text { Essig et al., } \\
2020[46]\end{array}$ & $\begin{array}{l}37 \text { acute ischemic stroke (AIS) } \\
\text { patients undergone mechani- } \\
\text { cal thrombectomy }\end{array}$ & H3Cit, NE, MPO & Immunofluorescence & $\begin{array}{l}\text { NETs found in more than } 90 \% \text { of thrombo- } \\
\text { emboli. NETs were almost exclusively found } \\
\text { within fibrin-rich areas }\end{array}$ \\
\hline $\begin{array}{l}\text { Zhou et al., } \\
2020[47]\end{array}$ & $\begin{array}{l}55 \text { AIS patients undergone } \\
\text { endovascular thrombectomy } \\
\text { and } 35 \text { healthy controls }\end{array}$ & $\begin{array}{l}\text { H3Cit, NE, MPO, } \\
\text { cfDNA }\end{array}$ & Immunofluorescence & $\begin{array}{l}\text { All NET-related markers found in plasma } \\
\text { were higher in AIS compared with control } \\
\text { group }\end{array}$ \\
\hline $\begin{array}{l}\text { Lim et al., } \\
2020[48]\end{array}$ & $\begin{array}{l}58 \text { AIS patients and } 25 \text { healthy } \\
\text { adults }\end{array}$ & $\begin{array}{l}\text { Double-stranded } \\
\text { DNA (dsDNA), } \\
\text { DNA-histone } \\
\text { complex }\end{array}$ & $\begin{array}{l}\text { Immunofluorescence (for } \\
\text { dsDNA) and ELISA (for } \\
\text { DNA-histone complex) }\end{array}$ & $\begin{array}{l}\text { Circulating levels of NETs was significantly } \\
\text { higher in AIS patients at initial presentation } \\
\text { compared with control group }\end{array}$ \\
\hline $\begin{array}{l}\text { Laridan et al., } \\
2017 \text { [49] }\end{array}$ & $\begin{array}{l}68 \text { AIS patients undergone } \\
\text { thrombectomy }\end{array}$ & H3Cit & Immunostaining & NETs was observed in almost all thrombi \\
\hline
\end{tabular}

Table 4. Animal studies of NETs in stroke

\begin{tabular}{|c|c|c|c|c|}
\hline Author, year & Species & Biomarkers & $\begin{array}{l}\text { Method used in } \\
\text { measurement of NETs }\end{array}$ & Results \\
\hline Kang et al., 2020 [50] & Mice & H3Cit & $\begin{array}{l}\text { Western Blot (ischemic cor- } \\
\text { tex) and immunostaining } \\
\text { (peri-infarct cortex) }\end{array}$ & $\begin{array}{l}\text { Cortex of ischemic mice have shown higher amount of } \\
\text { H3Cit }{ }^{+} \text {neutrophils. Peri-infarct cortex was extensively } \\
\text { labelled with H3Cit }{ }^{+} \text {cells after } 3 \text { days }\end{array}$ \\
\hline Kim et al., 2019 [51] & Rat & H3Cit & Immunofluorescence & $\begin{array}{l}\text { The first } \mathrm{H} 3 \mathrm{Cit}^{+} \text {cells entry occurred at } 12 \text { hours after } \\
\text { middle cerebral artery occlusion through leptomeninges }\end{array}$ \\
\hline $\begin{array}{l}\text { Perez-de-Puig et al., } 2015 \\
\text { [24] }\end{array}$ & Mice & H3Cit & Immunofluorescence & $\begin{array}{l}\mathrm{H} 3 \mathrm{Cit}^{+} \text {neutrophils found in perivascular spaces, cerebral } \\
\text { parenchyma near blood vessels, lumen capillaries, and } \\
\text { striatum }\end{array}$ \\
\hline
\end{tabular}




\section{NETs and procoagulant activity in blood vessels}

Impact of high levels of intravascular NET in SARS-CoV-2 can be explained in the vital role of circulating NETs to initiate and accrete thrombosis in artery and veins [53], also trigger occlusion of small vessels in lungs, heart, and kidneys [54]. In addition, NETs tend to form large aggregates which accelerate formation of thrombi in blood vessels at high neutrophil densities. Prothrombotic events and mechanism behind them are highly related to fibrin, tissue factor, and coagulation processes. The central role in thrombosis induced by NETs is promoting fibrin deposition and the establishment of fibrin networks [55] resulted in elevation of D-dimer level, the global indicator of coagulation activation and fibrinolysis [56], along with its procoagulant activities that induce coagulation system [18].

Coagulation increases the risk of getting thrombotic complications including ischemic stroke [57]. The proposed underlying pathological mechanism of NET-induced coagulation in COVID-19 is the ability of NETs to activate the plasma kallikrein-kinin system as the contact pathway of coagulation and its interaction with platelet. The kallikrein-kinin system can be activated through electrostatic interactions between histones of NET and platelet phospholipids [58]. Indeed, histones also act as ligands for Toll-like receptors on platelets, which induce platelet activation [59]. There is a well-established loop involving platelets and neutrophils. High Mobility Group protein B1 (HMGB1), a highly conserved nonhistone nuclear protein existed in platelet is a major endogenous inducer of NET formation. Activated platelets present HMGB1 to neutrophils and stimulate them to form NETs [18]. After adhesion process occurred, the chromatin of NET acts by disrupting epithelial lining, triggers platelet aggregation, so that it enhances further NET formation along with recruitment of neutrophils.

The foundation of NET-induced thrombus formation is by promoting platelet adhesion and concentrating coagulation factors to make a though clot. Extension of thrombi can be achieved by binding of thrombus-resident neutrophils and factor XII. In addition, activation of factor XII is supported by NETosis [60]. Apart from aforementioned mechanisms, there is an evidence for the release of tissue factor through NETs [61]. These lines of prothrombotic and hypercoagulable state-based mechanisms considered as the potential underlying events behind elevated levels of D-dimer as a reliable coagulation marker of severe COVID-19 cases. Supporting this idea, there is a study reported that patients with higher D-dimer levels show a significantly higher level of leukocytes and platelets in peripheral blood cell count test [62].

NET-induced endothelial dysfunction is a vital point in atherosclerosis [18], the fundamental events for pathogenesis of ischemic stroke. Two components of NETs; Cathepsin G and cathelicidins, induce the attraction of monocyte in atherosclerotic plaques [63]. Moreover, NETs are recognized as the major sources of Cathelicidin-related Antimicrobial Peptide (CRAMP). CRAMP is an endogenous antimicrobial polypeptide that is situated in secondary granule of neutrophil and deposited on inflamed endothelial surface [64]. NET-derived CRAMP anchors to endothelial cells then promote further monocyte recruitment. Another pathological mechanism underlying NET-induced endothelial dysfunction has done by MPO. After binding, MPO elevates the level of Reactive Oxygen Species (ROS). Further, ROS induces the production of oxidized Low Density Lipoprotein (oxLDL) which encourages the buildout of foam cells. Along with ROS, proteinase from NETs affects plaque instability [65].

Another proposed link in thrombus formation is the hyperinflammatory state induced in COVID-19. The complex mechanism of inflammation results in hyperviscosity, thrombogenesis, and higher stroke risk [52]. Severe COVID-19 is associated with a cytokine storm characterized by increased plasma concentrations of IL1 $\beta$, IL2, IL6, IL7, IL8, IL10, IL17, Interferon (IFN) $\gamma$, IFN $\gamma$-inducible protein 10 , monocyte chemoattractant protein 1 (MCP1), G-CSF, Macrophage Inflammatory Protein $1 \alpha$, and Tumor Necrosis Factor (TNF)a [28]. In addition to IL-17, IL-1 $\beta$ also induces the blood level of IL-6. Plasma IL-6 is widely studied as a strong predictor of ischemic stroke outcome [66]. Significant elevation in plasma, as well as brain tissue concentration of IL-6 or mRNA have been described in either clinical or experimental studies about ischemic stroke and transient ischemic attacks [6769]. A potent prothrombogenic properties of IL-6 presents in its ability to promote thrombocytosis secondary to stimulation of thrombopoiesis [70], induction of platelet-leukocyte aggregation [71], platelet activation [71], expression of tissue factor, fibrinogen, factor VIII and von Willebrand Factor (vWF), and thrombin generation. Another influence of IL- 6 on coagulation system is by reducing level of anti-thrombin and protein $S$ as the inhibitors of hemostasis [72].

Histone H4, one of main enzymes of NETs, has known to facilitate NETs to bind to host cell membranes by its high amount of cationic amino acid residues. This mechanism allows NETs to make pores on cell membranes, causing host smooth muscle cell lysis that leads to destabilization of plaques [73]. This role will exacerbate clot formation in blood vessels that leads into depletion of oxygen and nutrition in brain parenchyma.

\section{The NETs-induced neuroinflammation}

The interesting role of intravascular NETs after enhancing coagulation and prothrombotic pathway is orchestrating neuroinflammation, one of main pathological processes in every acute 
brain injury, including ischemic stroke. Disruption of blood flow after clot formation depletes the amount of cerebral oxygen and nutrients level. That deprivation of oxygen and nutrients results in neuronal damages followed by subsequent damage of BBB, glial cell activations and influx of circulating immune cells into cerebral parenchyma, worsening the progress of brain ischemia inducing neurological deficits [74-77]. Dying neurons and glial cells releases Damage Associated Molecular Pattern (DAMP) called HMGB1. Upon released, HMGB1 will interact with Toll-like Receptor4 (TLR4), results in activation of neutrophils, enhancement of NETosis in brain parenchyma, and activation of microglial cells. Activation of microglia will trigger more NETs release [45].

The mechanism of NETs-induced neuro inflammation seems to correlate with the action of neutrophil granules-derived enzymes along with its inflammatory events. In the brain parenchyma, extruded NETs components induce brain damage [44]. Allen et al. identified cathepsin-G and NE as the culprits of neuronal toxicity, and their inhibitors, when administered as a mixture, reported to reverse the neurotoxic effects of neutrophil. The study also revealed that the viability of cultured neurons depleted after 3 hours of administration of transmigrated neutrophils [78]. Another NETs enzyme, PAD4, showed a contribution in progression of brain damage upon NETosis. Inhibition of PAD4 using $\mathrm{Cl}$ amidine, the pan-PAD4 inhibitor, results in decrease of microglial activation, neuronal death, and infarct volume in a hypoxic ischemic mouse model [79].

Another interesting insight is NETs-IL-1 $\beta$ loop that exacerbates neuroinflammation. It is especially noteworthy that SARS-CoV-2 appears to act on the activation and maturation of IL- $1 \beta$. NETs trigger macrophages to secrete IL-1 $\beta[80]$. The significance of IL$1 \beta$ in stroke-related COVID pathogenesis is its role in inducing levels of IL- 17 and IL- 6 . IL-1 $\beta$ induces the release of IL-17 by activating Th17 cell [81]. Subsequently, pathogenic effect of IL-17 could be achieved through the interaction of IL-17 with its receptors existed on astrocytes, microglia, and neurons. The IL-17-IL17R signalling on astrocytes and microglial cells will activate the Nuclear Factor kappa-B (NFkB) transcriptional factors which is responsible for elevating the levels of proinflammatory cytokines (IL-6, TNF $\alpha$, and IL-1 $\beta$ ), chemokines (eg, CXCL1, CCL2, CXCL2, CCL7, CCL11, and CCL20), and metalloproteinases [82], amplifies the release of ROS, and enhance neutrophils accumulation in the brain parenchyma [83]. An experimental study using ischemic stroke model revealed that IL-17A-producing $\gamma \delta$ T cells have a pivotal role to enlarge infarct size [84]. Fig. 1 summarized the proposed pathological mechanism underlying NET-induced COVID-19-related ischemic stroke.

\section{THERAPEUTIC IMPLICATIONS AND FUTURE DIRECTIONS}

The ideas of NET involvement in COVID-related ischemic stroke has opened new horizon of therapeutic modalities. Based on its pathogenic mechanism, there are some different options could be offered as the potential therapeutic approaches related to NETs formation.

The inhibition of NET formation has established as either by blocking fundamental process involved in NETosis or disrupting the structure of NETs. However, the first option would not be feasible. The reason behind it is the high possibility of developing catastrophic adverse events. Inhibition of citrullination elevates the risk of carcinogenesis because citrullinated histones are not only important for chromatin decondensation, but also acts as an apoptotic code for detecting damaged cells [85]. On the other hand, targeting the dark side of NET either by disrupting DNA backbone of NET via DNase or antihistone modalities have been shown to be promising candidates to demolish pathological process in underlying diseases with excessive NET formation including Transfusion-Related Acute Lung Injury (TRALI) [86], Systemic Lupus Erythematosus (SLE) [87], and ischemic stroke [88]. Interesting result from a study revealed that administration of recombinant human DNAse 1 reduced infarct volumes and alleviated ischemic stroke outcome in mice [88].

However, the DNAse strategy does not optimally reduce the amount of NETosis because toxic histones remain attached to blood vessel wall [89], thus, next therapeutic approaches supporting pathological action of histones need to be considered. The histone depletion strategies can be achieved by blocking of extracellular histone toxicity using activated protein C [90]. Another approaches are heparin forms modification [91], C1 esterase inhibitor [92], antihistone antibodies, or blocking peptides [73]. Intranasal administration of PAD4 inhibitor results in less amount of NETosis, thus reduces inflammation by reducing immune cell infiltration and alleviates vasculogenesis [44].

A considerable number of scientific works are needed in order to complete the current understanding of the emerging relationship between COVID-19, NETs, and ischemic stroke. Preliminary studies about level of NETs and related factors in COVID-19-stroke patients can be designed in order to strengthen the foundation of this novel knowledge, indeed, with the consideration of ethical aspects for preparing such studies. We have already suggested a correlation between NETs, viral infection, and ischemic stroke by synthesizing studies. Targeting NETs in COVID-19 ischemic stroke, mechanistically, is a potential novel approach without any risks of general neutrophil depletion. Thus, whether the COVID-19 pandemic is still going on or not, studies correlating NETs 


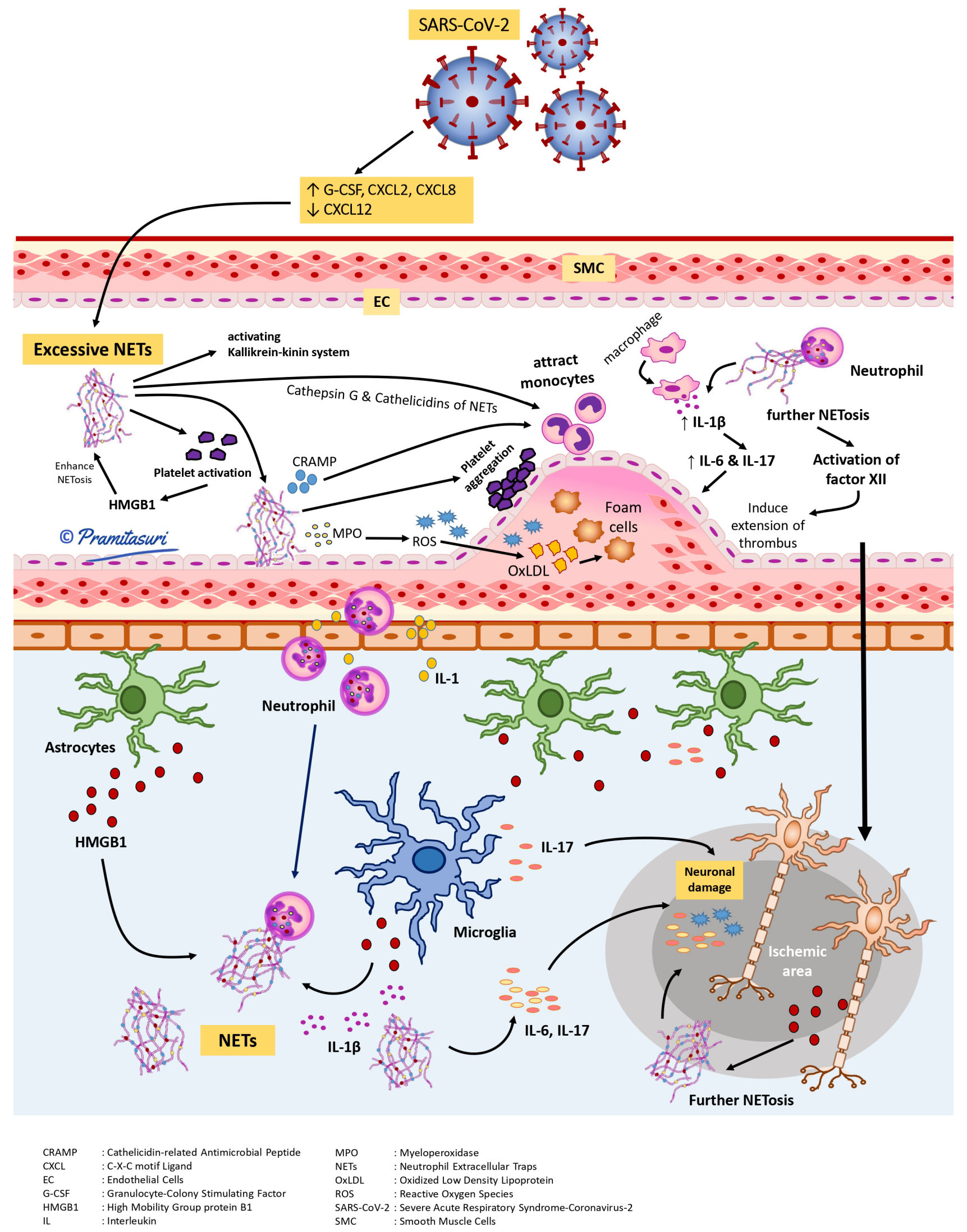

Fig. 1. NETs in the pathogenesis of COVID-19-associated ischemic stroke. 
and ischemic stroke is a worth-to-explore topic in neuroscience field.

\section{CONCLUSION}

The establishment of NET as a potential driver in a series of pathological mechanisms in COVID-19-related ischemic stroke, including coagulation, inflammatory state, and endothelial dysfunction, is an important novel finding in neurology. Inhibition of NETs formation are potential clinical implications in the sphere of NETs-induced COVID-19-related ischemic stroke. Beyond of its fascinating role and aside of COVID-19, NET is a strategic research object in either exploring pathogenesis, drug prospecting studies, and even reversing rTPA resistance among ischemic stroke patients.

\section{ACKNOWLEDGEMENTS}

The authors thanked Anak Agung Ayu Putri Laksmidewi, MD, Ph.D and Ida Bagus Kusuma Putra, MD for their constructive criticisms of the manuscript and expertise regarding knowledge and horizons of neurovascular disorders.

\section{REFERENCES}

1. Oxley T), Mocco J, Majidi S, Kellner CP, Shoirah H, Singh IP, De Leacy RA, Shigematsu T, Ladner TR, Yaeger KA, Skliut M, Weinberger J, Dangayach NS, Bederson JB, Tuhrim S, Fifi JT (2020) Large-vessel stroke as a presenting feature of Covid-19 in the young. N Engl J Med 382:e60.

2. Al-Anazi KA, Al-Anazi WK, Al-Jasser AM (2020) Neutrophils, NETs, NETosis and their paradoxical roles in COVID-19. J Stem Cell Ther Transplant 4:3-10.

3. Barnes BJ, Adrover JM, Baxter-Stoltzfus A, Borczuk A, CoolsLartigue J, Crawford JM, Daßler-Plenker J, Guerci P, Huynh C, Knight JS, Loda M, Looney MR, McAllister F, Rayes R, Renaud S, Rousseau S, Salvatore S, Schwartz RE, Spicer JD, Yost CC, Weber A, Zuo Y, Egeblad M (2020) Targeting potential drivers of COVID-19: neutrophil extracellular traps. J Exp Med 217:e20200652.

4. Zuo Y, Yalavarthi S, Shi H, Gockman K, Zuo M, Madison JA, Blair C, Weber A, Barnes BJ, Egeblad M, Woods RJ, Kanthi Y, Knight JS (2020) Neutrophil extracellular traps in COVID-19. JCI Insight 5:e138999.

5. Boehme AK, Luna J, Kulick ER, Kamel H, Elkind MSV (2018) Influenza-like illness as a trigger for ischemic stroke. Ann Clin Transl Neurol 5:456-463.
6. Katz JM, Libman RB, Wang JJ, Sanelli P, Filippi CG, Gribko M, Pacia SV, Kuzniecky RI, Najjar S, Azhar S (2020) Cerebrovascular complications of COVID-19. Stroke 51:e227-e231.

7. Mao L, Jin H, Wang M, Hu Y, Chen S, He Q, Chang J, Hong C, Zhou Y, Wang D, Miao X, Li Y, Hu B (2020) Neurologic manifestations of hospitalized patients with coronavirus disease 2019 in Wuhan, China. JAMA Neurol 77:683-690.

8. Lodigiani C, Iapichino G, Carenzo L, Cecconi M, Ferrazzi P, Sebastian T, Kucher N, Studt JD, Sacco C, Bertuzzi A, Sandri MT, Barco S; Humanitas COVID-19 Task Force (2020) Venous and arterial thromboembolic complications in COVID-19 patients admitted to an academic hospital in Milan, Italy. Thromb Res 191:9-14.

9. Yaghi S, Ishida K, Torres J, Mac Grory B, Raz E, Humbert K, Henninger N, Trivedi T, Lillemoe K, Alam S, Sanger M, Kim S, Scher E, Dehkharghani S, Wachs M, Tanweer O, Volpicelli F, Bosworth B, Lord A, Frontera J (2020) SARS-CoV-2 and stroke in a New York healthcare system. Stroke 51:2002-2011.

10. Helms J, Kremer S, Merdji H, Clere-Jehl R, Schenck M, Kummerlen C, Collange O, Boulay C, Fafi-Kremer S, Ohana M, Anheim M, Meziani F (2020) Neurologic features in severe SARS-CoV-2 infection. N Engl J Med 382:2268-2270.

11. Klok FA, Kruip MJHA, van der Meer NJM, Arbous MS, Gommers D, Kant KM, Kaptein FHJ, van Paassen J, Stals MAM, Huisman MV, Endeman H (2020) Confirmation of the high cumulative incidence of thrombotic complications in critically ill ICU patients with COVID-19: an updated analysis. Thromb Res 191:148-150.

12. Tan YK, Goh C, Leow AST, Tambyah PA, Ang A, Yap ES, Tu TM, Sharma VK, Yeo LLL, Chan BPL, Tan BYQ (2020) COVID-19 and ischemic stroke: a systematic review and metasummary of the literature. J Thromb Thrombolysis 50:587595.

13. Ornello R, Degan D, Tiseo C, Di Carmine C, Perciballi L, Pistoia F, Carolei A, Sacco S (2018) Distribution and temporal trends from 1993 to 2015 of ischemic stroke subtypes: a systematic review and meta-analysis. Stroke 49:814-819.

14. Bhatia R, Pedapati R, Komakula S, Srivastava MVP, Vishnubhatla S, Khurana D (2020) Stroke in coronavirus disease 2019: a systematic review. J Stroke 22:324-335.

15. Jillella DV, Janocko NJ, Nahab F, Benameur K, Greene JG, Wright WL, Obideen M, Rangaraju S (2020) Ischemic stroke in COVID-19: an urgent need for early identification and management. PLoS One 15:e0239443.

16. Brinkmann V, Reichard U, Goosmann C, Fauler B, Uhlemann Y, Weiss DS, Weinrauch Y, Zychlinsky A (2004) Neutrophil extracellular traps kill bacteria. Science 303:1532-1535. 
17. Galani IE, Andreakos E (2015) Neutrophils in viral infections: current concepts and caveats. J Leukoc Biol 98:557-564.

18. Bonaventura A, Vecchié A, Abbate A, Montecucco F (2020) Neutrophil extracellular traps and cardiovascular diseases: an update. Cells 9:231.

19. Papayannopoulos V, Metzler KD, Hakkim A, Zychlinsky A (2010) Neutrophil elastase and myeloperoxidase regulate the formation of neutrophil extracellular traps. J Cell Biol 191:677-691.

20. Sollberger G, Choidas A, Burn GL, Habenberger P, Di Lucrezia R, Kordes S, Menninger S, Eickhoff J, Nussbaumer P, Klebl B, Krüger R, Herzig A, Zychlinsky A (2018) Gasdermin D plays a vital role in the generation of neutrophil extracellular traps. Sci Immunol 3:eaar6689.

21. Hemmers S, Teijaro JR, Arandjelovic S, Mowen KA (2011) PAD4-mediated neutrophil extracellular trap formation is not required for immunity against influenza infection. PLoS One 6:e22043.

22. Li P, Li M, Lindberg MR, Kennett MJ, Xiong N, Wang Y (2010) PAD4 is essential for antibacterial innate immunity mediated by neutrophil extracellular traps. J Exp Med 207:1853-1862.

23. Thålin C, Daleskog M, Göransson SP, Schatzberg D, Lasselin J, Laska AC, Kallner A, Helleday T, Wallén H, Demers M (2017) Validation of an enzyme-linked immunosorbent assay for the quantification of citrullinated histone $\mathrm{H} 3$ as a marker for neutrophil extracellular traps in human plasma. Immunol Res 65:706-712.

24. Perez-de-Puig I, Miró-Mur F, Ferrer-Ferrer M, Gelpi E, Pedragosa J, Justicia C, Urra X, Chamorro A, Planas AM (2015) Neutrophil recruitment to the brain in mouse and human ischemic stroke. Acta Neuropathol 129:239-257.

25. Vallés J, Lago A, Santos MT, Latorre AM, Tembl JI, Salom JB, Nieves C, Moscardó A (2017) Neutrophil extracellular traps are increased in patients with acute ischemic stroke: prognostic significance. Thromb Haemost 117:1919-1929.

26. Wang D, Hu B, Hu C, Zhu F, Liu X, Zhang J, Wang B, Xiang H, Cheng Z, Xiong Y, Zhao Y, Li Y, Wang X, Peng Z (2020) Clinical characteristics of 138 hospitalized patients with 2019 novel coronavirus-infected pneumonia in Wuhan, China. JAMA 323:1061-1069.

27. Yao XH, Li TY, He ZC, Ping YF, Liu HW, Yu SC, Mou HM, Wang LH, Zhang HR, Fu WJ, Luo T, Liu F, Guo QN, Chen C, Xiao HL, Guo HT, Lin S, Xiang DF, Shi Y, Pan GQ, Li QR, Huang X, Cui Y, Liu XZ, Tang W, Pan PF, Huang XQ, Ding YQ, Bian XW (2020) [A pathological report of three COVID-19 cases by minimal invasive autopsies]. Zhonghua Bing Li Xue Za Zhi 49:411-417. Chinese.
28. Huang C, Wang Y, Li X, Ren L, Zhao J, Hu Y, Zhang L, Fan G, Xu J, Gu X, Cheng Z, Yu T, Xia J, Wei Y, Wu W, Xie X, Yin W, Li H, Liu M, Xiao Y, Gao H, Guo L, Xie J, Wang G, Jiang R, Gao Z, Jin Q, Wang J, Cao B (2020) Clinical features of patients infected with 2019 novel coronavirus in Wuhan, China. Lancet 395:497-506.

29. Christopher MJ, Link DC (2007) Regulation of neutrophil homeostasis. Curr Opin Hematol 14:3-8.

30. Blanco-Melo D, Nilsson-Payant BE, Liu WC, Uhl S, Hoagland D, Møller R, Jordan TX, Oishi K, Panis M, Sachs D, Wang TT, Schwartz RE, Lim JK, Albrecht RA, tenOever BR (2020) Imbalanced host response to SARS-CoV-2 drives development of COVID-19. Cell 181:1036-1045.e9.

31. Fox SE, Akmatbekov A, Harbert JL, Li G, Quincy Brown J, Vander Heide RS (2020) Pulmonary and cardiac pathology in African American patients with COVID-19: an autopsy series from New Orleans. Lancet Respir Med 8:681-686.

32. Qin C, Zhou L, Hu Z, Zhang S, Yang S, Tao Y, Xie C, Ma K, Shang K, Wang W, Tian DS (2020) Dysregulation of immune response in patients with coronavirus 2019 (COVID-19) in Wuhan, China. Clin Infect Dis 71:762-768.

33. Zhang B, Zhou X, Zhu C, Song Y, Feng F, Qiu Y, Feng J, Jia Q, Song Q, Zhu B, Wang J (2020) Immune phenotyping based on the neutrophil-to-lymphocyte ratio and IgG level predicts disease severity and outcome for patients With COVID-19. Front Mol Biosci 7:157.

34. Zhang J, Cai L, Song Y, Shan B, He M, Ren Q, Chen C, Liu Z, Zeng Y, Xu J (2017) Prognostic role of neutrophil lymphocyte ratio in patients with spontaneous intracerebral hemorrhage. Oncotarget 8:77752-77760.

35. Zhang J, Ren Q, Song Y, He M, Zeng Y, Liu Z, Xu J (2017) Prognostic role of neutrophil-lymphocyte ratio in patients with acute ischemic stroke. Medicine (Baltimore) 96:e8624.

36. Jenne CN, Wong CH, Zemp FJ, McDonald B, Rahman MM, Forsyth PA, McFadden G, Kubes P (2013) Neutrophils recruited to sites of infection protect from virus challenge by releasing neutrophil extracellular traps. Cell Host Microbe 13:169-180.

37. Nicolai L, Leunig A, Brambs S, Kaiser R, Weinberger T, Weigand M, Muenchhoff M, Hellmuth JC, Ledderose S, Schulz H, Scherer C, Rudelius M, Zoller M, Höchter D, Keppler O, Teupser D, Zwißler B, von Bergwelt-Baildon M, Kääb S, Massberg S, Pekayvaz K, Stark K (2020) Immunothrombotic dysregulation in COVID-19 pneumonia is associated with respiratory failure and coagulopathy. Circulation 142:11761189.

38. Zuo Y, Zuo M, Yalavarthi S, Gockman K, Madison JA, Shi H, 
Woodard W, Lezak SP, Lugogo NL, Knight JS, Kanthi Y (2020) Neutrophil extracellular traps and thrombosis in COVID-19. J Thromb Thrombolysis 51:446-453.

39. Middleton EA, He XY, Denorme F, Campbell RA, Ng D, Salvatore SP, Mostyka M, Baxter-Stoltzfus A, Borczuk AC, Loda M, Cody MJ, Manne BK, Portier I, Harris ES, Petrey AC, Beswick EJ, Caulin AF, Iovino A, Abegglen LM, Weyrich AS, Rondina MT, Egeblad M, Schiffman JD, Yost CC (2020) Neutrophil extracellular traps contribute to immunothrombosis in COVID-19 acute respiratory distress syndrome. Blood 136:1169-1179.

40. Veras FP, Pontelli MC, Silva CM, Toller-Kawahisa JE, de Lima M, Nascimento DC, Schneider AH, Caetité D, Tavares LA, Paiva IM, Rosales R, Colón D, Martins R, Castro IA, Almeida GM, Lopes MIF, Benatti MN, Bonjorno LP, Giannini MC, Luppino-Assad R, Almeida SL, Vilar F, Santana R, Bollela VR, Auxiliadora-Martins M, Borges M, Miranda CH, PazinFilho A, da Silva LLP, Cunha LD, Zamboni DS, Dal-Pizzol F, Leiria LO, Siyuan L, Batah S, Fabro A, Mauad T, Dolhnikoff M, Duarte-Neto A, Saldiva P, Cunha TM, Alves-Filho JC, Arruda E, Louzada-Junior P, Oliveira RD, Cunha FQ (2020) SARS$\mathrm{CoV}$-2-triggered neutrophil extracellular traps mediate COVID-19 pathology. J Exp Med 217:e20201129.

41. Peña-Martínez C, Durán-Laforet V, García-Culebras A, Ostos F, Hernández-Jiménez M, Bravo-Ferrer I, Pérez-Ruiz A, Ballenilla F, Díaz-Guzmán J, Pradillo JM, Lizasoain I, Moro MA (2019) Pharmacological modulation of neutrophil extracellular traps reverses thrombotic stroke tPA (tissue-type plasminogen activator) resistance. Stroke 50:3228-3237.

42. Emsley HC, Tyrrell PJ (2002) Inflammation and infection in clinical stroke. J Cereb Blood Flow Metab 22:1399-1419.

43. Kim JY, Park J, Chang JY, Kim SH, Lee JE (2016) Inflammation after ischemic stroke: the role of leukocytes and glial cells. Exp Neurobiol 25:241-251.

44. Kim SW, Lee JK (2020) Role of HMGB1 in the interplay between NETosis and thrombosis in ischemic stroke: a review. Cells 9:1794.

45. Manda-Handzlik A, Demkow U (2019) The brain entangled: the contribution of neutrophil extracellular traps to the diseases of the central nervous system. Cells 8:1477.

46. Essig F, Kollikowski AM, Pham M, Solymosi L, Stoll G, Haeusler KG, Kraft P, Schuhmann MK (2020) Immunohistological analysis of neutrophils and neutrophil extracellular traps in human thrombemboli causing acute ischemic stroke. Int J Mol Sci 21:7387.

47. Zhou P, Li T, Jin J, Liu Y, Li B, Sun Q, Tian J, Zhao H, Liu Z, Ma S, Zhang S, Novakovic VA, Shi J, Hu S (2020) Interactions between neutrophil extracellular traps and activated platelets enhance procoagulant activity in acute stroke patients with ICA occlusion. EBioMedicine 53:102671.

48. Lim HH, Jeong IH, An GD, Woo KS, Kim KH, Kim JM, Yun SH, Park JI, Cha JK, Kim MH, Han JY (2020) Evaluation of neutrophil extracellular traps as the circulating marker for patients with acute coronary syndrome and acute ischemic stroke. J Clin Lab Anal 34:e23190.

49. Laridan E, Denorme F, Desender L, François O, Andersson T, Deckmyn H, Vanhoorelbeke K, De Meyer SF (2017) Neutrophil extracellular traps in ischemic stroke thrombi. Ann Neurol 82:223-232.

50. Kang L, Yu H, Yang X, Zhu Y, Bai X, Wang R, Cao Y, Xu H, Luo H, Lu L, Shi MJ, Tian Y, Fan W, Zhao BQ (2020) Neutrophil extracellular traps released by neutrophils impair revascularization and vascular remodeling after stroke. Nat Commun 11:2488.

51. Kim SW, Lee H, Lee HK, Kim ID, Lee JK (2019) Neutrophil extracellular trap induced by HMGB1 exacerbates damages in the ischemic brain. Acta Neuropathol Commun 7:94.

52. Valderrama EV, Humbert K, Lord A, Frontera J, Yaghi S (2020) Severe acute respiratory syndrome coronavirus 2 infection and ischemic stroke. Stroke 51:e124-e127.

53. Fuchs TA, Brill A, Wagner DD (2012) Neutrophil extracellular trap (NET) impact on deep vein thrombosis. Arterioscler Thromb Vasc Biol 32:1777-1783.

54. Cedervall J, Zhang Y, Huang H, Zhang L, Femel J, Dimberg A, Olsson AK (2015) Neutrophil extracellular traps accumulate in peripheral blood vessels and compromise organ function in tumor-bearing animals. Cancer Res 75:2653-2662.

55. Fuchs TA, Brill A, Duerschmied D, Schatzberg D, Monestier M, Myers DD Jr, Wrobleski SK, Wakefield TW, Hartwig JH, Wagner DD (2010) Extracellular DNA traps promote thrombosis. Proc Natl Acad Sci U S A 107:15880-15885.

56. Bates SM (2012) D-dimer assays in diagnosis and management of thrombotic and bleeding disorders. Semin Thromb Hemost 38:673-682.

57. Moore HB, Barrett CD, Moore EE, McIntyre RC, Moore PK, Talmor DS, Moore FA, Yaffe MB (2020) Is there a role for tissue plasminogen activator as a novel treatment for refractory COVID-19 associated acute respiratory distress syndrome? J Trauma Acute Care Surg 88:713-714.

58. Oehmcke S, Mörgelin M, Herwald H (2009) Activation of the human contact system on neutrophil extracellular traps. J Innate Immun 1:225-230.

59. Semeraro F, Ammollo CT, Morrissey JH, Dale GL, Friese P, Esmon NL, Esmon CT (2011) Extracellular histones pro- 
mote thrombin generation through platelet-dependent mechanisms: involvement of platelet TLR2 and TLR4. Blood 118:1952-1961.

60. von Brühl ML, Stark K, Steinhart A, Chandraratne S, Konrad I, Lorenz M, Khandoga A, Tirniceriu A, Coletti R, Köllnberger M, Byrne RA, Laitinen I, Walch A, Brill A, Pfeiler S, Manukyan D, Braun S, Lange P, Riegger J, Ware J, Eckart A, Haidari S, Rudelius M, Schulz C, Echtler K, Brinkmann V, Schwaiger M, Preissner KT, Wagner DD, Mackman N, Engelmann B, Massberg S (2012) Monocytes, neutrophils, and platelets cooperate to initiate and propagate venous thrombosis in mice in vivo. J Exp Med 209:819-835.

61. Kambas K, Mitroulis I, Apostolidou E, Girod A, Chrysanthopoulou A, Pneumatikos I, Skendros P, Kourtzelis I, Koffa M, Kotsianidis I, Ritis K (2012) Autophagy mediates the delivery of thrombogenic tissue factor to neutrophil extracellular traps in human sepsis. PLoS One 7:e45427.

62. Ma TT, Huang YM, Wang C, Zhao MH, Chen M (2014) Coagulation and fibrinolysis index profile in patients with ANCA-associated vasculitis. PLoS One 9:e97843.

63. Wang J, Sjöberg S, Tang TT, Oörni K, Wu W, Liu C, Secco B, Tia V, Sukhova GK, Fernandes C, Lesner A, Kovanen PT, Libby P, Cheng X, Shi GP (2014) Cathepsin G activity lowers plasma LDL and reduces atherosclerosis. Biochim Biophys Acta 1842:2174-2183.

64. Wantha S, Alard JE, Megens RT, van der Does AM, Döring Y, Drechsler M, Pham CT, Wang MW, Wang JM, Gallo RL, von Hundelshausen P, Lindbom L, Hackeng T, Weber C, Soehnlein O (2013) Neutrophil-derived cathelicidin promotes adhesion of classical monocytes. Circ Res 112:792-801.

65. Carbone F, Mach F, Montecucco F (2015) Update on the role of neutrophils in atherosclerotic plaque vulnerability. Curr Drug Targets 16:321-333.

66. Aref HMA, Fahmy NA, Khalil SH, Ahmed MF, ElSadek A, Abdulghani MO (2020) Role of interleukin-6 in ischemic stroke outcome. Egypt J Neurol Psychiatry Neurosurg 56:12.

67. Gertz K, Kronenberg G, Kälin RE, Baldinger T, Werner C, Balkaya M, Eom GD, Hellmann-Regen J, Kröber J, Miller KR, Lindauer U, Laufs U, Dirnagl U, Heppner FL, Endres M (2012) Essential role of interleukin-6 in post-stroke angiogenesis. Brain 135(Pt 6):1964-1980.

68. Offner H, Vandenbark AA, Hurn PD (2009) Effect of experimental stroke on peripheral immunity: CNS ischemia induces profound immunosuppression. Neuroscience 158:10981111.

69. Terao S, Yilmaz G, Stokes KY, Ishikawa M, Kawase T, Granger DN (2008) Inflammatory and injury responses to ischemic stroke in obese mice. Stroke 39:943-950.

70. Zhang L, Lukowski R, Gaertner F, Lorenz M, Legate KR, Domes K, Angermeier E, Hofmann F, Massberg S (2013) Thrombocytosis as a response to high interleukin-6 levels in cGMP-dependent protein kinase I mutant mice. Arterioscler Thromb Vasc Biol 33:1820-1828.

71. Yan SL, Russell J, Granger DN (2014) Platelet activation and platelet-leukocyte aggregation elicited in experimental colitis are mediated by interleukin-6. Inflamm Bowel Dis 20:353362.

72. Tuttolomondo A, Di Raimondo D, di Sciacca R, Pinto A, Licata $\mathrm{G}$ (2008) Inflammatory cytokines in acute ischemic stroke. Curr Pharm Des 14:3574-3589.

73. Silvestre-Roig C, Braster Q, Wichapong K, Lee EY, Teulon JM, Berrebeh N, Winter J, Adrover JM, Santos GS, Froese A, Lemnitzer P, Ortega-Gómez A, Chevre R, Marschner J, Schumski A, Winter C, Perez-Olivares L, Pan C, Paulin N, Schoufour T, Hartwig H, González-Ramos S, Kamp F, Megens RTA, Mowen KA, Gunzer M, Maegdefessel L, Hackeng T, Lutgens E, Daemen M, von Blume J, Anders HJ, Nikolaev VO, Pellequer JL, Weber C, Hidalgo A, Nicolaes GAF, Wong GCL, Soehnlein O (2019) Externalized histone H4 orchestrates chronic inflammation by inducing lytic cell death. Nature 569:236-240.

74. Gelderblom M, Leypoldt F, Steinbach K, Behrens D, Choe CU, Siler DA, Arumugam TV, Orthey E, Gerloff C, Tolosa E, Magnus T (2009) Temporal and spatial dynamics of cerebral immune cell accumulation in stroke. Stroke 40:1849-1857.

75. Schilling M, Besselmann M, Leonhard C, Mueller M, Ringelstein EB, Kiefer R (2003) Microglial activation precedes and predominates over macrophage infiltration in transient focal cerebral ischemia: a study in green fluorescent protein transgenic bone marrow chimeric mice. Exp Neurol 183:25-33.

76. Schilling M, Strecker JK, Schäbitz WR, Ringelstein EB, Kiefer R (2009) Effects of monocyte chemoattractant protein 1 on blood-borne cell recruitment after transient focal cerebral ischemia in mice. Neuroscience 161:806-812.

77. Schuette-Nuetgen K, Strecker JK, Minnerup J, Ringelstein EB, Schilling M (2012) MCP-1/CCR-2-double-deficiency severely impairs the migration of hematogenous inflammatory cells following transient cerebral ischemia in mice. Exp Neurol 233:849-858.

78. Allen C, Thornton P, Denes A, McColl BW, Pierozynski A, Monestier M, Pinteaux E, Rothwell NJ, Allan SM (2012) Neutrophil cerebrovascular transmigration triggers rapid neurotoxicity through release of proteases associated with decondensed DNA. J Immunol 189:381-392.

79. Lange S, Rocha-Ferreira E, Thei L, Mawjee P, Bennett K, 
Thompson PR, Subramanian V, Nicholas AP, Peebles D, Hristova M, Raivich G (2014) Peptidylarginine deiminases: novel drug targets for prevention of neuronal damage following hypoxic ischemic insult (HI) in neonates. J Neurochem 130:555-562.

80. Meher AK, Spinosa M, Davis JP, Pope N, Laubach VE, Su G, Serbulea V, Leitinger N, Ailawadi G, Upchurch GR Jr (2018) Novel role of IL (interleukin)-1 $\beta$ in neutrophil extracellular trap formation and abdominal aortic aneurysms. Arterioscler Thromb Vasc Biol 38:843-853.

81. Qi H, Yang S, Zhang L (2017) Neutrophil extracellular traps and endothelial dysfunction in atherosclerosis and thrombosis. Front Immunol 8:928.

82. Hu X, De Silva TM, Chen J, Faraci FM (2017) Cerebral vascular disease and neurovascular injury in ischemic stroke. Circ Res 120:449-471.

83. Benakis C, Brea D, Caballero S, Faraco G, Moore J, Murphy M, Sita G, Racchumi G, Ling L, Pamer EG, Iadecola C, Anrather J (2016) Commensal microbiota affects ischemic stroke outcome by regulating intestinal $\gamma \delta$ T cells. Nat Med 22:516-523.

84. Shichita T, Sugiyama Y, Ooboshi H, Sugimori H, Nakagawa R, Takada I, Iwaki T, Okada Y, Iida M, Cua DJ, Iwakura Y, Yoshimura A (2009) Pivotal role of cerebral interleukin-17-producing gammadeltaT cells in the delayed phase of ischemic brain injury. Nat Med 15:946-950.

85. Tanikawa C, Espinosa M, Suzuki A, Masuda K, Yamamoto K, Tsuchiya E, Ueda K, Daigo Y, Nakamura Y, Matsuda K (2012) Regulation of histone modification and chromatin structure by the p53-PADI4 pathway. Nat Commun 3:676.

86. Caudrillier A, Kessenbrock K, Gilliss BM, Nguyen JX, Marques MB, Monestier M, Toy P,Werb Z, Looney MR (2012)
Platelets induce neutrophil extracellular traps in transfusionrelated acute lung injury. J Clin Invest 122:2661-2671.

87. Leffler J, Martin M, Gullstrand B, Tydén H, Lood C, Truedsson L, Bengtsson AA, Blom AM (2012) Neutrophil extracellular traps that are not degraded in systemic lupus erythematosus activate complement exacerbating the disease. J Immunol 188:3522-3531.

88. De Meyer SF, Suidan GL, Fuchs TA, Monestier M, Wagner DD (2012) Extracellular chromatin is an important mediator of ischemic stroke in mice. Arterioscler Thromb Vasc Biol 32:1884-1891.

89. Kolaczkowska E, Jenne CN, Surewaard BG, Thanabalasuriar A, Lee WY, Sanz MJ, Mowen K, Opdenakker G, Kubes P (2015) Molecular mechanisms of NET formation and degradation revealed by intravital imaging in the liver vasculature. Nat Commun 6:6673.

90. Xu J, Zhang X, Pelayo R, Monestier M, Ammollo CT, Semeraro F, Taylor FB, Esmon NL, Lupu F, Esmon CT (2009) Extracellular histones are major mediators of death in sepsis. Nat Med 15:1318-1321.

91. Rasmuson J, Kenne E, Wahlgren M, Soehnlein O, Lindbom L (2019) Heparinoid sevuparin inhibits Streptococcus-induced vascular leak through neutralizing neutrophil-derived proteins. FASEB J 33:10443-10452.

92. Wygrecka M, Kosanovic D, Wujak L, Reppe K, Henneke I, Frey H, Didiasova M, Kwapiszewska G, Marsh LM, Baal N, Hackstein H, Zakrzewicz D, Müller-Redetzky HC, de Maat S, Maas C, Nolte MW, Panousis C, Schermuly RT, Seeger W, Witzenrath M, Schaefer L, Markart P (2017) Antihistone properties of $\mathrm{C} 1$ esterase inhibitor protect against lung injury. Am J Respir Crit Care Med 196:186-199. 